\title{
A natural-stone city walk through Maastricht, the Netherlands*
}

\author{
C.W. Dubelaar ${ }^{1,}{ }^{*}$, P.J.M. Kisters ${ }^{2} \&$ J.W. Stroucken ${ }^{3}$ \\ 1 TN0-Geological Survey of the Netherlands, Princetonlaan 6, NL-3584 CB Utrecht, the Netherlands. \\ 2 Natuurhistorisch Museum Maastricht, de Bosquetplein 6-7, NL-6211 KJ Maastricht, the Netherlands. \\ 3 Caumerboord 5, NL-6418 BK Heerlen, the Netherlands. \\ * Corresponding author. Email: wim.dubelaar@tno.nl.
}

Manuscript received: March 2011, accepted: July 2011

\begin{abstract}
Having been inspired by the leaflet, 'Natuursteen in Maastricht. Aardrijkskunde in een oude stad', written by P.J. Felder and published in 1977, we here present descriptions of the main types of natural stones applied in the city of Maastricht. A concise overview of the provenance area, mineralogy and physical properties of a selection of so-called historical building stones used in Maastricht, from Roman times onwards, is given. On a walk, starting at the Natuurhistorisch Museum Maastricht and ending at the Vrijthof, the main square of the city of Maastricht, details of building stones seen on the way are highlighted.
\end{abstract}

Keywords: building stones, geological walk, Maastricht

\section{Introduction}

The late Felder brothers, Sjeuf and Werner, were widely acclaimed as excellent teachers who were highly skilled in passing on their extensive knowledge of regional geology and archaeology to a very diverse audience, scholars and non-professionals alike. On the occasion of the opening of the completely refurbished Natuurhistorisch Museum Maastricht in 1977, the Natuurhistorisch Genootschap Limburg published a leaflet entitled, 'Natuursteen in Maastricht. Aardrijkskunde in een oude stad' (see also P.J. Felder, 1977). In that leaflet, Sjeuf leads the visitor on a stroll through the oldest part of the city of Maastricht, describing the wide range of building stones used in pavements, city walls and house exteriors. In the present paper, we offer an extended and revised version of that 1977 publication.

\section{Building stones in the Netherlands}

Most near-surface deposits in the Netherlands consist of unconsolidated Cenozoic sediments; outcrops of natural stone suitable for building purposes are very rare. Locally, in the northern part of the country, use was made of large boulders, transported from Scandinavia by glaciers during the Saalian Ice Age (middle Pleistocene). Bog iron ores from upper Pleistocene and lower Holocene deposits have been used, albeit on a very small scale, as a building material from mediaeval times onwards in the southern and eastern part of the country (Slinger et al., 1980; Nijland et al., 2006). In the province of Limburg, cobbles and boulders originating from the Ardennes region and deposited by precursors of the River Maas (Meuse), were exploited during the Middle Ages and used for pavements and walls. In the valley of the River Geul, near the border with Belgium, Upper Carboniferous quartz-cemented sandstones were excavated at a few quarries (Fig. 1) and were used mainly for masonry in farmsteads not far from the quarry (Bosch, 1989). The most widely distributed native building stones are different lithotypes of the Upper Cretaceous Maastricht limestone sequence (see next pages).

From data on the scarce occurrences of natural stone in the Netherlands it is clear that building stones had to be imported.

* In: Jagt, J.W.M., Jagt-Yazykova, E.A. \& Schins, W.J.H. (eds): A tribute to the late Felder brothers - pioneers of Limburg geology and prehistoric archaeology. 


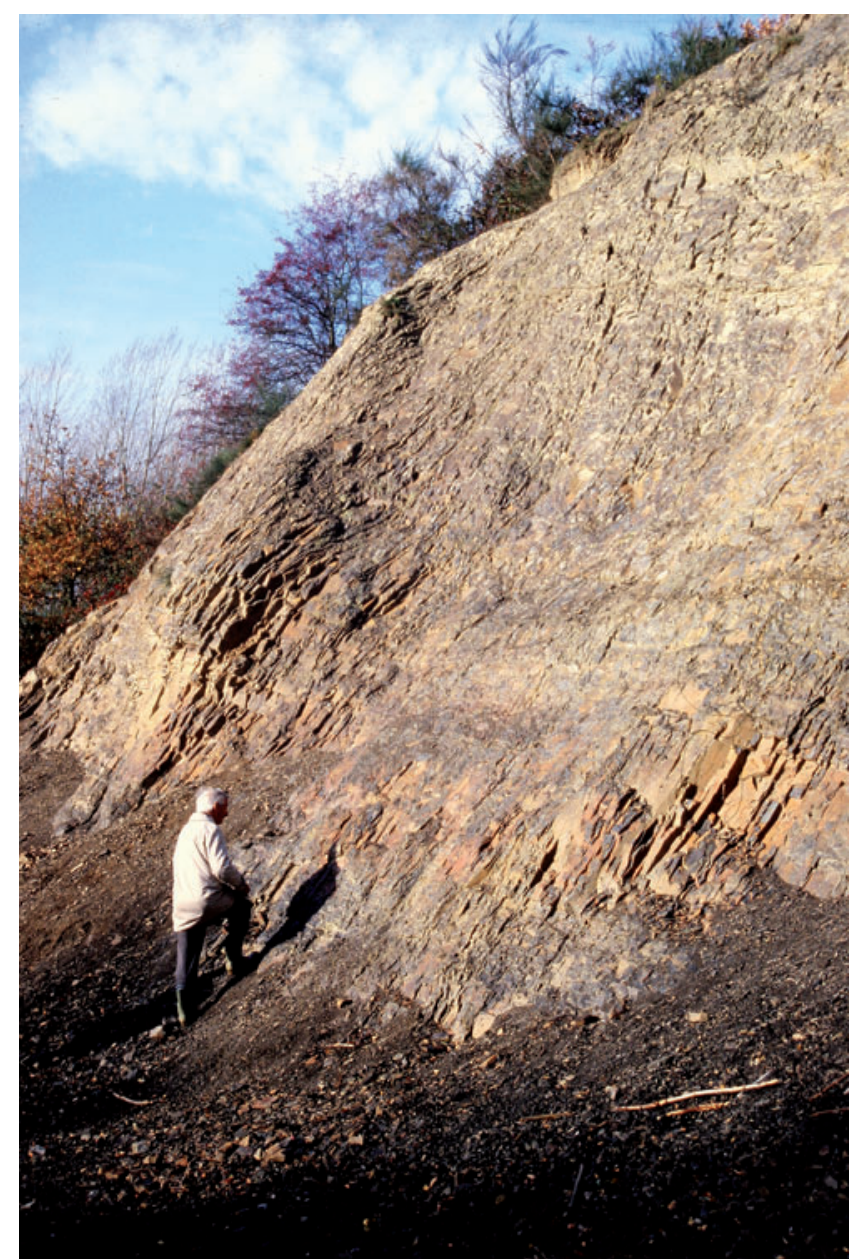

Fig. 1. Werner M. Felder at the foot of the Upper Carboniferous sandstone sequence at Cottessen quarry.

Among the natural stones from abroad are different types of rocks, e.g. basalt, slate and volcanic tuff from the Eifel region (Germany) and sandstones, such as Bentheim Sandstone from Lower Saxony (Germany). From Champagne-Lorraine and Burgundy in the Paris Basin came Mesozoic and Cenozoic limestones, especially during the second half of the nineteenth century and the first half of the twentieth (e.g., Slinger et al., 1980; Dubelaar, 1984; Nijland et al., 2007). Several types of blue-coloured limestone of Early Carboniferous age, from southern Belgium, became the most widespread dimension stone in the Netherlands. Nowadays, a large part of the natural stones applied are imported from Asia, Africa and South America.

\section{The historical building stones of Maastricht}

After a brief introduction of the founding of Maastricht an overview is presented below of the main types of building stones used in the city for houses and pavements up to the first half of the twentieth century. To discriminate these stones from the great variety and global provenance of recent building material we refer to these rocks as 'historical building stones'.
Maastricht traces its origins to a riverside fortification which the Romans named Trajectum ad Mosam. In the first century $\mathrm{AD}$, the Romans built a wooden bridge to serve as a vital link in the Via Belgica, the route that connected Köln (Cologne), in Germany, to Bavay, in northern France. The River Maas was the second important transportation route and so a small trade settlement naturally formed at the intersection of the road with the river. The bridge connected the two banks at about where the Plankstraat and Hoogbrugstraat are today. The St. Servaasbrug (St Servatius Bridge), slightly to the north, is the mediaeval successor to the Roman bridge. In the fourth century, the Romans also constructed a fortified camp, a so-called castrum. All that remains of this oldest known fortification is the base of a wall tower, which is preserved in the courtyard of the Onze Lieve Vrouw Basiliek (Basilica of Our Beloved Lady). A municipal centre started to develop here in mediaeval times, surrounded by an earthen wall that provided the first form of protection and security. Stone walls were eventually built around the city, turning Maastricht into a truly fortified city.

\section{Maastricht limestone}

The Upper Cretaceous (upper Maastrichtian) limestone deposits of the Maastricht Formation in the southern part of Limburg, locally referred to as 'mergel', provide the major supply of Dutch natural stone (W.M. Felder \& Bosch, 2000). The building stone became known as Maastricht stone or Maastricht limestone (Jongmans, 1943; Dreesen et al., 2002; Dubelaar et al., 2006b). Underground mining by room and pillar workings were initiated as early as the thirteenth century (Van Westreenen, 1988) and Maastricht limestone constituted the predominant building stone in Gothic and Renaissance-style buildings. In later times, this limestone was used on a more limited scale, for ornaments and other decorative sculptures, but it has been in constant use until the present day. Maastricht limestone is often employed in combination with Lower Carboniferous limestone from Belgium (also known as bluestone or, in Dutch, 'hardsteen'), with the Maastricht limestone being used for wall coping, framed by corner stones of Carboniferous limestone. The St. Pietersberg (Mount St Peter) and the surrounding area show extensive subterranean galleries from which the building stones were taken (Fig. 2). The limestone (Maastricht Formation, Nekum Member) is currently mined in two underground quarries in the Valkenburg-Sibbe area, mainly for restoration works and extraction amounts to about 500 cubic metres per annum. As local architects regularly apply the limestone as cladding in modern buildings demand is assumed to increase in the future. Most of the present use of Maastricht Formation limestone is in the Portland cement industry, with the ENCIHeidelberg Cement Group quarry south of Maastricht as the most important production factory. 


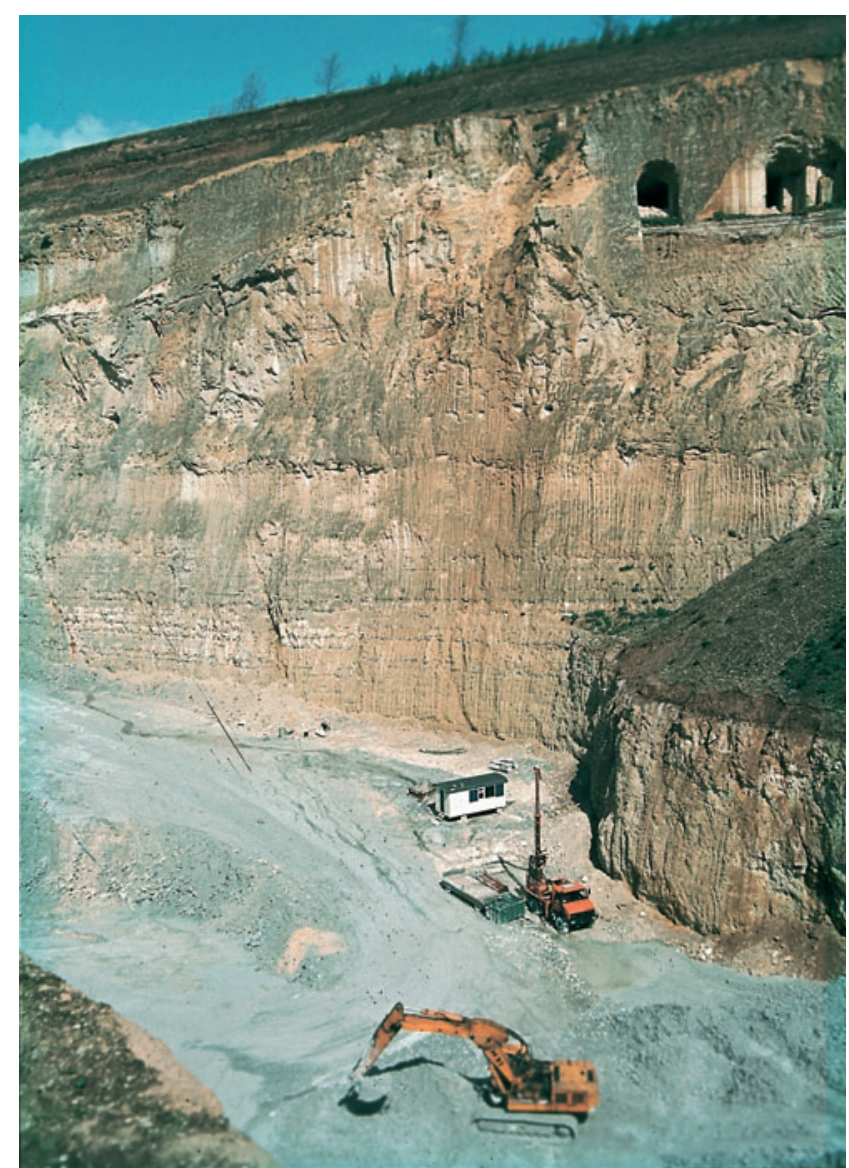

Fig.2. ENCI-Heidelberg Cement Group quarry. Former underground galleries are visible in the upper right-hand corner. Photograph TNOGeological Survey of the Netherlands (2000).

The Maastricht Formation occurs near the surface in a restricted belt of about 40 kilometres in width, between the cities of Tongeren (Belgium), Maastricht, Heerlen and Aachen (Germany). Several stone qualities are recognised, based on regional facies types. The main facies types in the marine bioclastic carbonate sands of the Maastricht Formation are the so-called Maastricht and Kunrade facies (W.M. Felder \& Bosch, 2000). Among the soft building stones of the Maastricht facies, the Zichen, Sibbe and Kanne block types can be distinguished, based on their fossil content and diagenetic fingerprint. The Kunrade facies (Kunrade limestone) shows an alternation of soft and hard layers of limestone containing some quartz cement. The Kunrade facies is restricted in distribution to a small region southwest of Heerlen. This rock type, cut and hewn until about 1960, can be found primarily in buildings at Heerlen and direct vicinity (Jongmans, 1943; Bosch, 1989). However, in the 1920s it reached as far north as Amsterdam (Dubelaar, 1984). All carbonate facies types comprise predominantly bioclasts of sand size, exhibiting a calcarenitic (grainstone) fabric. They consist of very pure limestone (94-98 per cent $\mathrm{CaCO}_{3}$ ) with slight differences in colour, mineralogy, cement and fossil fragments (foraminifera, bivalves, gastropods and echinoids). Porosity is up to 40-50 volume per cent. The grains are loosely packed and cementation is related mostly to syntaxial cements overgrowing echinoderm ossicles (Dreesen et al., 2002). In spite of the low compressive strength (5-30 MPa or even less), the durability of the soft Maastricht limestone is remarkably high. Joints are relatively infrequent and widely spaced. Due to the high porosity and connecting intergranular pore spaces the Maastricht limestone is only slightly sensitive to frost action, or not at all (Dubelaar et al., 2006b).

\section{Flint}

Flint belongs to a group of rock types rich in cryptocrystalline silica, with a fair degree of hardness, sharp cutting edges and a conchoidal fracture. Flint originating from flint levels, or in the form of nodules, in the Upper Cretaceous limestone has been used as early as 6000 years BP for making tools (Bosch, 1979). Flint has been used sparsely as building stone in the southern part of Limburg near the places of outcrop. At present, flint is a by-product of the limestone quarries and is used mainly as road metal and for hydraulic engineering purposes (Engelen, 1989).

\section{Lower Carboniferous limestone}

Within the Lower Carboniferous limestone levels in the Ardennes, used as a building stone, a clear distinction exists between three types of stone: the so-called Tournai limestone, the Namur limestone and the 'petit granit' (Slinger et al., 1980; Dusar et al., 2009). The first-named, exposed in semi-natural outcrops along the River Schelde (Scheldt) at Tournai, has been exploited from Roman times onwards. The Namur limestone, the purest one with a carbonate content of up to 98 per cent, has traditionally been mined in quarries situated directly along the River Meuse, between Namur and Huy. The third group of limestone of the Lower Carboniferous is the freestone, also known as Belgian bluestone (Dutch: Belgische hardsteen), paving stone, crinoidal limestone or 'petit granit'. The crinoidal limestone and the Tournai limestone are of Tournaisian age (c. $350 \mathrm{Ma}$ ); the Namur stone is slightly younger (Visean, c. $340 \mathrm{Ma}$ ).

Over the years, there has been a shift in the prevailing type of limestone brought to the Netherlands. It is obvious that the ways of transport, the rivers Maas and Schelde, determined in considerable extent the geographical distribution of the different Carboniferous limestones. In the late Middle Ages the Tournai limestone appears as a building stone in the provinces of Zeeland and Zuid-Holland, while the Namur stone was applied mainly in Limburg, Brabant and in the central Netherlands. The closing of the River Schelde in 1585 marked the end of the export of the building stones from the Schelde basin to the Low Countries in the north and as a consequence the trade in Tournai limestone diminished considerably (Janse \& De Vries, 1991; Van Tussenbroek, 2006). The supply and use of Namur stone waned (Middle Ages extending through to the seventeenth century, 
then less common), while more and more the crinoidal limestone from Ecausinnes and Soignies (Hainaut) was preferred (fifteenth century to the present day). When the Ardennes became more accessible with the construction of a railroad network in the nineteenth century, stone from other quarries, such as those in the Ourthe valley (near Liège), were transported to the Netherlands. Currently, freestone is excavated in several very large quarries in the province of Hainaut, near Soignies (Fig. 3), in a few smaller quarries in the Condroz, between Namur and Dinant (Bocq valley) and near Sprimont in the Ourthe area (Dusar et al., 2009).

The crinoidal limestone or 'petit granit' can be recognised by the countless fragments of crinoids (sea lilies) and the occurrence of bryozoans, corals (e.g., Zaphrentis, a cyathophylloid), brachiopods and gastropods. The crinoid stems are magnesiumrich calcium carbonate crystals, the split surfaces of which glisten in the sunlight when the stone is fractured. At such times, in the stonemason's eye, the fresh surface of the stone resembles granite - hence the vernacular name 'petit granit' (Groessens, 1993). A particular feature of freestone from Belgium is that the stone exudes a sulphurous odour when cut or hewn. The sulphur is released from the thin black, bituminous layers in veins (partly evolved as stylolites) distributed throughout the stone.

\section{Famennian sandstone (Condroz psammite)}

The Famennian (Upper Devonian) sandstone is a marine, micaceous, fine-grained very tight arkosic sandstone found in the area known as the Condroz (Ardennes). The feldspars are fresh and sand grains are well cemented by carbonate and/or quartz, resulting in a very low porosity of less than 1 per cent
(Dreesen \& Dusar, 2004). The dark brown to greyish blue sandstone is very well stratified with mica plates parallel to the bedding plane making it easy to split it. The durable Famennian sandstone, first exploited in the Middle Ages in small quarries, was combined with roughly hewn blocks of Maas boulders, Carboniferous sandstone and flint in the plinths of the oldest churches at Maastricht. The sandstones have sparsely been used as wall inlay for the city walls. Application widened considerably in the second half of the nineteenth century when new infrastructure works, such as railways, resulted in better transport facilities of the stones from the quarries in the Ardennes.

\section{Carboniferous sandstone}

Most of the Upper Carboniferous (Westphalian) sandstones used as building stone most probably were derived from outcrops in the Meuse valley southwest of Liège. The Carboniferous sandstone outcropping in that area is a litharenitic sandstone of fluvial origin, occasionally showing coal fragments and weathered lithoclasts. On account of clayey lithoclasts, the resistance against physical weathering of the Carboniferous sandstone is generally less than that of the Famennian sandstone (Dreesen \& Dusar, 2004). The traditional style was to combine the Carboniferous sandstone with flint nodules from the Upper Cretaceous Maastricht limestone, a fine example of which can be found in the oldest city wall sections of Maastricht. Carboniferous sandstone, also known in the Netherlands as 'kolenzandsteen', and quartzitic sandstone of the Upper Carboniferous (Westphalian), mined from quarries in the River Geul valley to the southeast of Epen (Heimans, Kamp and Cottessen quarries; see Fig.1), might be found in Maastricht, albeit on a limited scale.

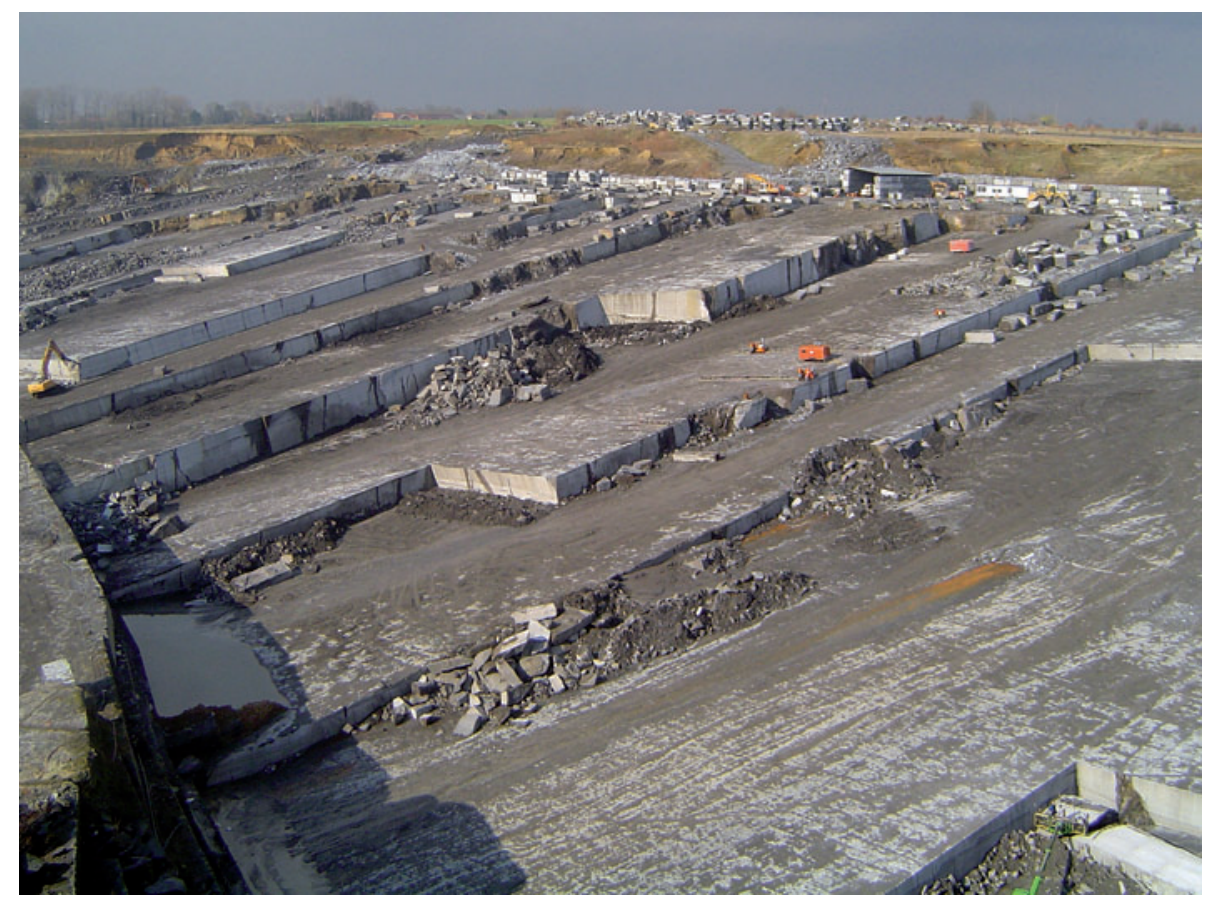

Fig. 3. Exploitation of Lower Carboniferous limestone at Soignies (Hainaut, southern Belgium). 


\section{Nivelstein sandstone}

The Nivelstein sandstone is a very pure (almost 100 per cent quartz) sandstone which occurs as lenticular bodies in nonlithified sands of Miocene age (Breda Formation, Heksenberg Member) along the Germany/Netherlands border, east of Kerkrade (Bosch, 1989; Grimm, 1990). It was used in Roman times, e.g. for sarcophagi and border stones. Nivelstein sandstone was applied during mediaeval times in Romanesque church-related constructions. In Maastricht the stone can be found, for example, in the St. Servaaskerk (early Middle Ages) and in the plinth of the HeiligHart-van-Jezuskerk built in the 1930s (Nijland et al., 2006).

\section{Maas boulders}

Not to be overlooked are boulders and gravel-size clasts from River Maas deposits that have been used as building material in the past. Excavations performed in Maastricht in 2005 at the site of the Mosae Forum near the town hall, revealed a late Mediaeval floor constructed of cobbles taken from such sediments.

\section{The natural-stone city walk}

The walking tour is about one mile $(1.6 \mathrm{~km})$ long. It starts at the Natuurhistorisch Museum Maastricht (De Bosquetplein) and ends at the Vrijthof, the main square of Maastricht. Excursion points are indicated on the city map (Fig. 4). Most rock types encountered are placed in a simplified geological time chart (Fig. 20).

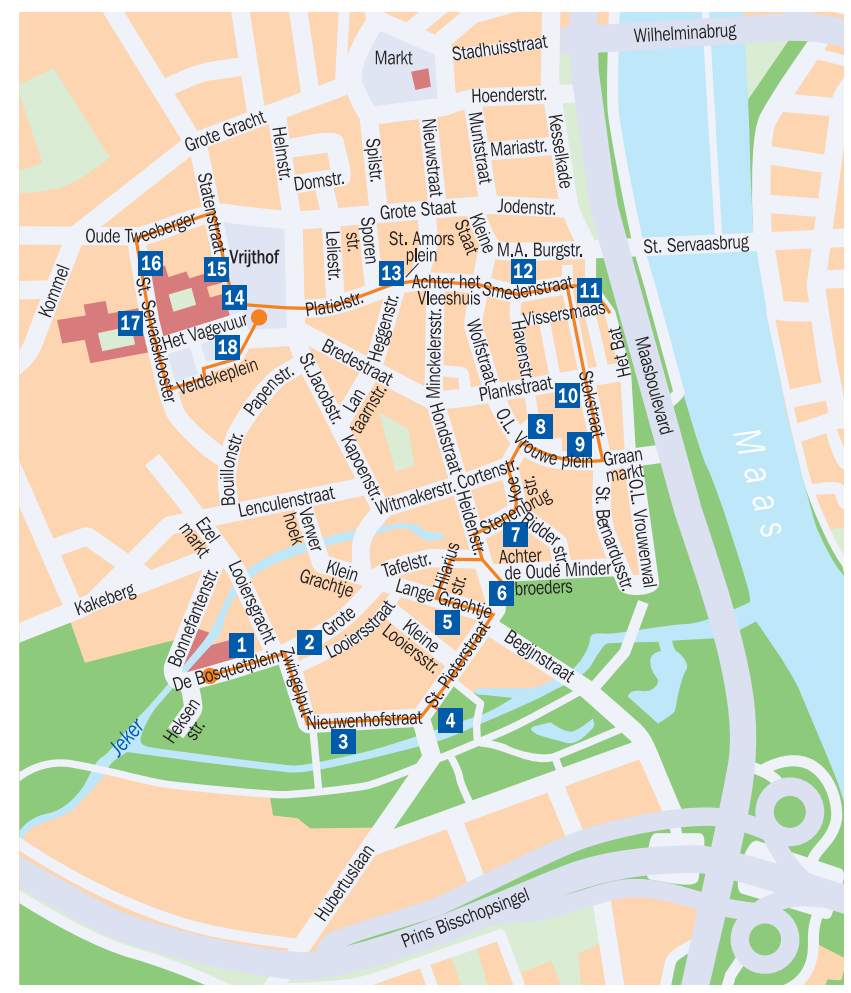

Fig. 4. Route map of the natural-stone city walk.

\section{1-2}

As we leave the museum through the main entrance, traversing granite cobblestones laid out in a nice fan pattern, we walk passed a row of massive stone slabs. The first two, of Devillian Quartzite from the Stavelot Massif in northeast Belgium, lean against the brick walls and form a sort of geological gateway. Past the bench on the right are five more large slabs, put together. These are boulders of sandstone, quartzite and conglomerate transported from the French and Belgian Ardennes by precursors of the present-day River Maas. The purplish red Early/Middle Devonian Burnot Conglomerate shows a typical 'poudingue' (puddingstone) structure (Fig. 5). The pebbles, up to several centimetres in size, generally are not in contact but occur scattered throughout the finer-grained, quartz-rich groundmass. A well-known but minor constituent (<10 per cent) is dark tourmalinite, whose genesis has been examined by Corteel \& Van den haute (2002), among others. Those authors concluded that the conglomerates were subjected to a post-depositional mineralisation involving quartz, chlorite and tourmaline.

\section{3}

The group of bronze sculptures, a tribute to Fons Olterdissen, Maastricht-born composer of rhymes and operettas, are on a foundation of beige-coloured, tight limestone. The limestone presumably originates from Jurassic levels in France (Comblanchien quarry, near Beaune in Burgundy).

\section{4}

Continue along the Nieuwenhofstraat, which is parallel to the Second City Wall. This city wall, built in the fourteenth and fifteenth centuries, is made of large blocks of yellow- to ochrecoloured Maastricht limestone ('mergel') interspersed with an occasional block of dark-brown Carboniferous sandstone. The soft Maastricht limestone is damaged in many places, revealing the creamy yellow, fine-grained porous structure of the stone behind the hard, blackened outer layer. This layer consists of a thin veneer of newly formed calcite with gypsum that incorporates black soot.

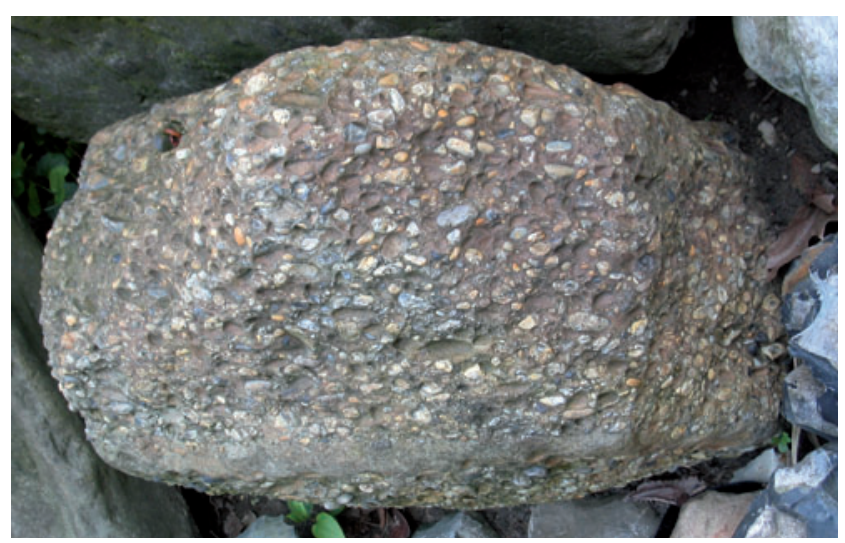

Fig. 5. Boulder of Burnot Conglomerate in the garden of the Natuurhistorisch Museum Maastricht. 
The greyish blue to silvery grey Carboniferous limestone used in the arches was mined from quarries in the Meuse valley, in the area near Namur, hence the name used in the old accounts, 'Namur stone'. This limestone, of Visean age, can easily be distinguished from the crinoidal limestone of Tournaisian age by its fossil content and fine-grained appearance. Most of the Namur stones used as building blocks are micro-stromatolithic boundstones. Characteristic features are small, nearly closed joints, more or less vertical to the stratification. These planes of stress, often hidden in the tight fine-grained limestone, become more conspicuous when the rock is taken from the quarry and is exposed to weathering.

The old mill house and mill passageway along the River Jeker, a tributary of the Maas, can be reached through a small gate on the Pieterstraat. The River Jeker, which enters the city from the south, has its origin southwest of Waremme in Belgium. At Waterpoort De Reek, the river splits into two courses, one of which enters the city where in earlier times it was largely an area of open water. The tanners in the Grote Looiersstraat and Kleine Looiersstraat commonly used Jeker water. In the blocks of the gatehouse facade the Maastricht limestone clearly reveals shell layers and bands of calcareous tube worms, Pyrgopolon mosae. The highest-quality building stone does not usually contain any thick shell strata but a thin layer of shells or other fossils in the stone is not generally considered a flaw. It contributes to the living, varied character of the Maastricht limestone. The plinth and window frames in the houses, as well as the slabs on the bridge over the mill passageway, are made of blue Namur limestone. The slabs of the bridge have been abraded by centuries of use, splendidly revealing the tension fissures in the stone that are filled with white calcite (Fig. 6). The mason's cutting traces (chisel marks) are still evident on the upright side of these blocks (Fig. 7).

\section{5}

The city wall, dating from 1229, runs along the Lange Grachtje (Long Canal). It contains different kinds of brownish micaceous grey sandstone, of various shapes and sizes, laid out in an

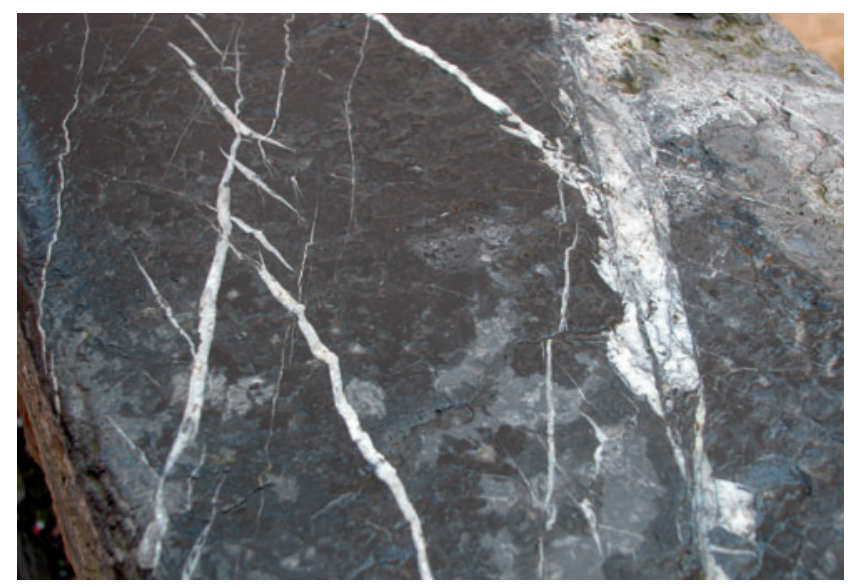

Fig. 6. Boundstone (Namur limestone) with tension joints.

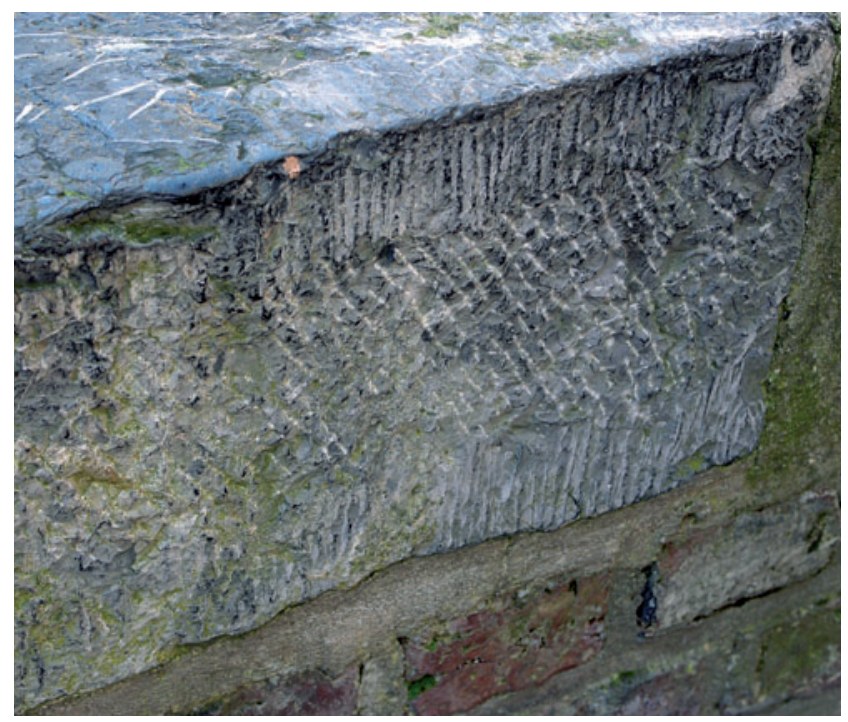

Fig. 7. Stonemason's chisel marks on Namur limestone slab. Bridge to the old mill at the River Jeker.

irregular pattern. The surface of some of the sandstones has rust brown, highly ferruginous crusts, formed by oxidation of iron in the clayey mineral components. The majority of the stones are of Late Devonian (Famennian) and Late Carboniferous age, having been quarried from different places in the Belgian Ardennes. The wall also has an occasional bit of Maastricht limestone.

\section{6}

The Franciskanerkerk (Franciscan Church), which now houses part of the Rijksarchief (State Archives), dates back to the thirteenth century. The plinth is constructed from a variety of sandstones, including Carboniferous sandstone, Devonian sandstone and Burnot Sandstone (Fig. 8), with the occasional use of brick and some flint (Fig. 9). The facade shows a predominance of Maastricht limestone that contains a great many macrofossil fragments. In the greyish blue Namur limestone, to the right, in the corner, the cross section of a large calcitic shell of a nautiloid cephalopod (Fig.10) can be seen.

\section{7}

Continue along the Stenenbrug and Ridderstraat, to reach the Bisschopsmolen (Bishop's Mill), a well-restored, seventeenthcentury mill house with an impressive water wheel. Here again, yellow Maastricht stone was used in combination with Namur stone. The threshold of the building at Koestraat 11, shows the distinctive honeycomb pattern of the colonial coral Michelinia, a characteristic fossil in the Lower Carboniferous crinoidal limestone. This bioclastic, coarse-grained limestone, more commonly known as 'petit granit', was used widely throughout the city from the seventeenth century onwards. This bluestone replaced the purer carbonate, fine-grained Namur stone (which was selected for cement production) in the course of the nineteenth century. 


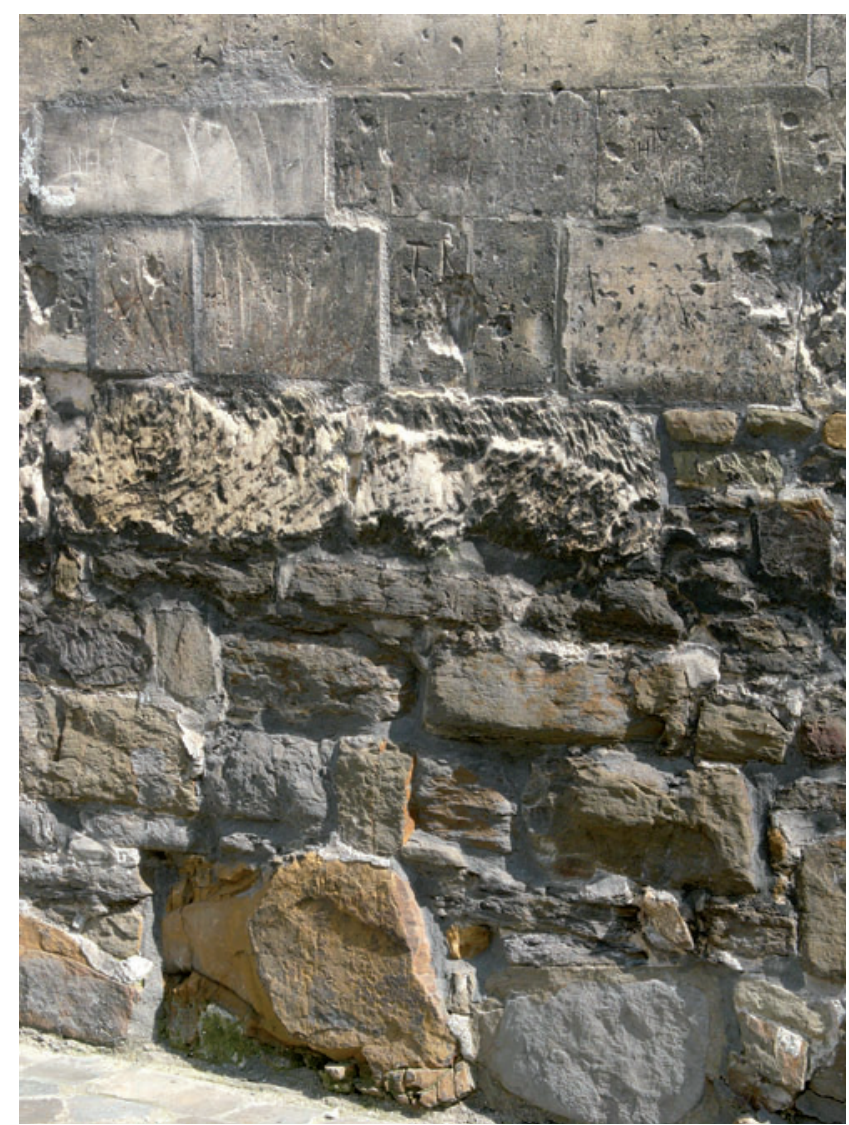

Fig. 8. Wall of Upper Carboniferous sandstone and Maastricht limestone (Franciscan church).

8

At Onze Lieve Vrouweplein 21, 'The house with the pelican' is found, a bank building in the so-called Jugendstil architectural style, that has a striking silhouette. The facade coping of yellow calcareous sandstone, presumably originating from Triassic levels in Luxemburg, rests on Lower Carboniferous limestone. The Onze Lieve Vrouw Basiliek (Basilica of Our Beloved Lady) across the square is a mediaeval cruciform church, the oldest

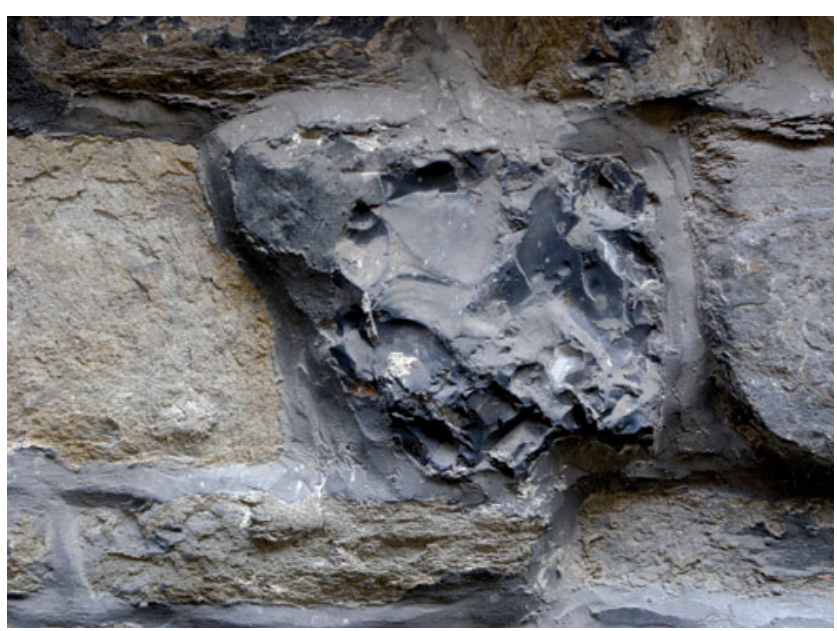

Fig. 9. Flint from the Maastricht Formation in the plinth of the Franciscan church.

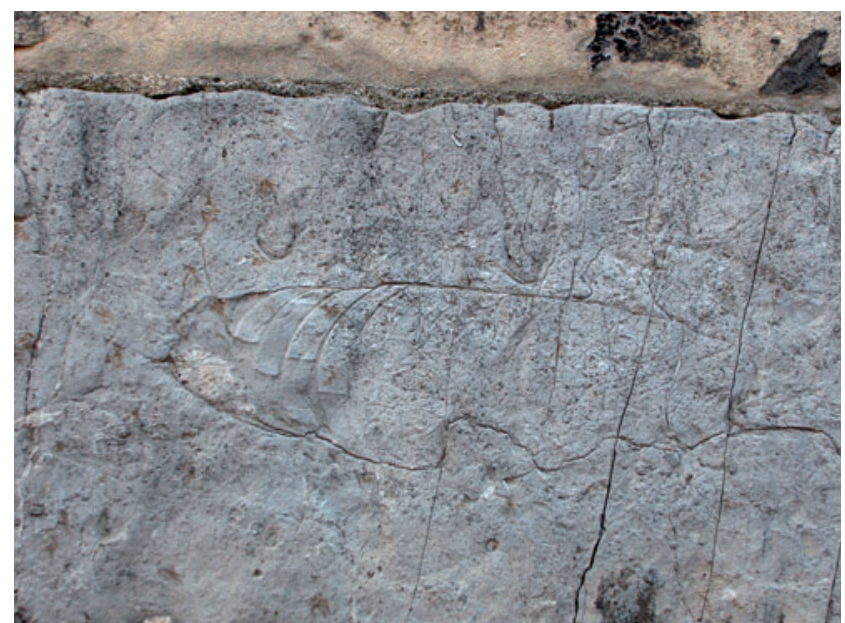

Fig. 10. Lower Carboniferous Namur limestone (boundstone lithotype) showing a cross section of a nautiloid shell.

part of which dates back to the eleventh century. The majestic face of this basilica is characterised by its construction of Maastricht limestone on top of Carboniferous sandstone and Namur limestone (Fig. 11). Flint has also been used in some places. The large limestone blocks in the plinth may have been recycled from the Roman fortress of Maastricht.

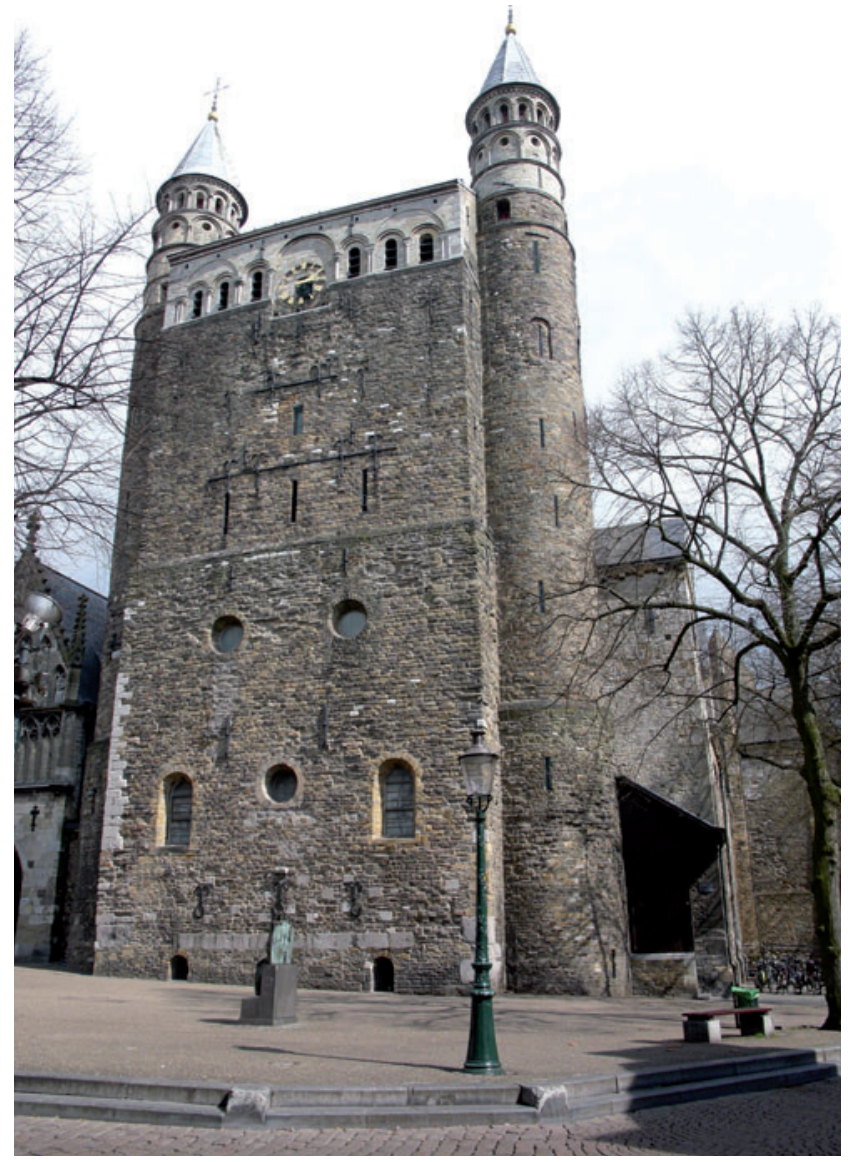

Fig. 11. Basilica of Our Beloved Lady: Maastricht limestone on top of Carboniferous sandstone and large blocks of Namur limestone. 


\section{9}

The Militair Wachthuisje (Sentry House) from 1786, on the corner of the Graanmarkt and Stokstraat, consists primarily of grey boundstone from the Meuse valley near Namur. This stratified limestone is generally laid horizontally but here some of the blocks have been set with the stratification vertical (Fig. 12). The stone weathers and erodes much more quickly and the limestone clearly flakes off in some places. It is highly probable that the stones were cleaned recently and, regrettably, much of their original surface was removed. The cleaning also enhances the progressive weathering of the stone.

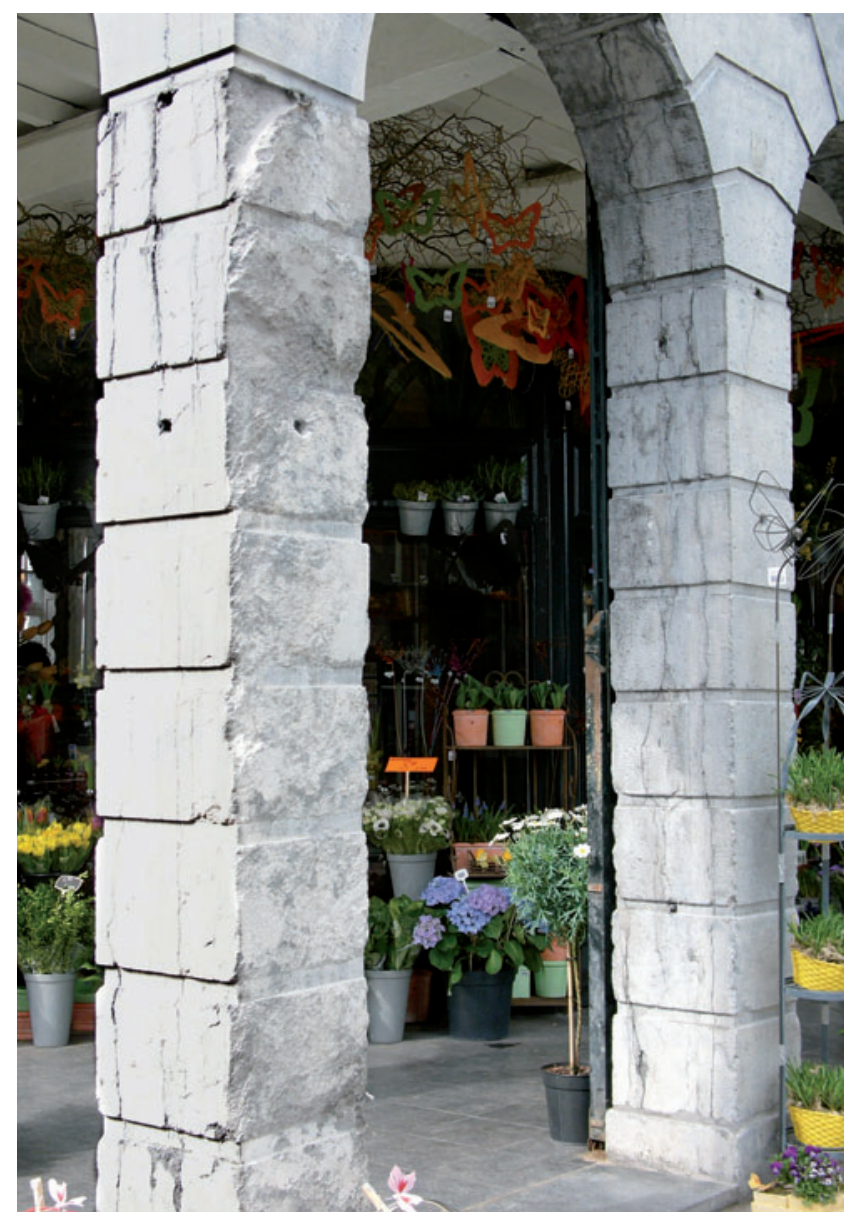

Fig. 12. Namur limestone columns of the portal of the Sentry House, built in 1786 .

\section{0}

At Stokstraat 59 stands a handsome building with a facade of brick, layered with Maastricht limestone. The pavement of the Stokstraat and of the Plankstraat, which intersects it, is comprised of small, very compact, dark blue limestone blocks which show coral fragments and well-preserved crinoid columnals. The internal fabric of the crinoids and solitary corals are particularly well visible in the ornamental paving around the bronze statue in the Plankstraat (Fig. 13). These limestone cobblestones of Devonian age were mined from a quarry in the Condroz, a region in the south of the Belgian Ardennes.

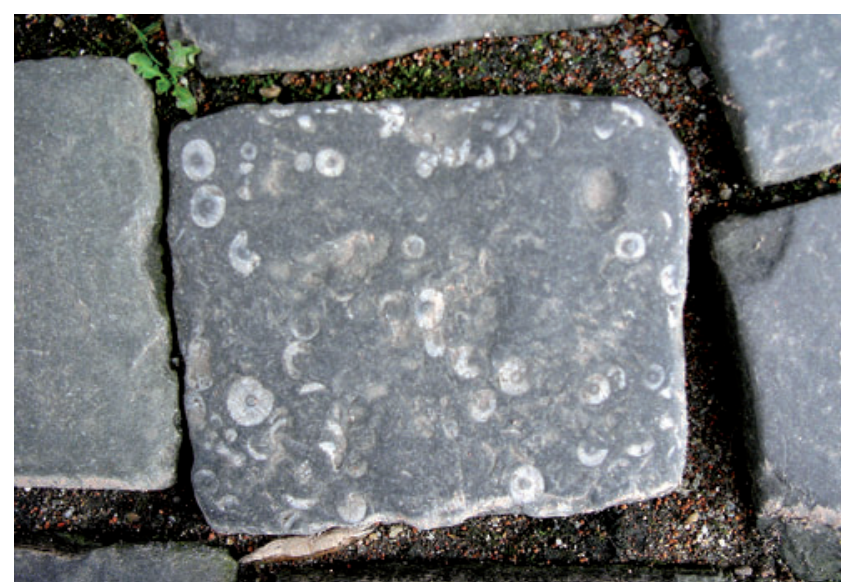

Fig. 13. Crinoids and coral fragments in Devonian cobblestone, Plankstraat.

\section{1}

At the end of the Stokstraat turn right and continue into the Vissersmaas; proceed down the steps to Het Bat. The stone steps are made of a fine-grained, greyish pink granite, presumably from the Vosges in France. From this vantage point, we have a nice view of the St. Servaasbrug (from 1280) spanning the Maas (Fig. 14). From a distance, the light grey natural stone of this bridge resembles the stone that was originally used, the Namur limestone. But when the bridge was repaired in 1931, much of the original stone was replaced with rather different limestone types: Rocville (from the Ain Département, France) and Rocbois, a Middle Jurassic (Bathonian) oolithic limestone also known as Chauvigny, from a quarry near Poitiers, France (Lijdsman 1944; Pomerol, 1992).

\section{2}

Head back along the 'Pothuiske' to the Maastrichter Smedenstraat, where houses at numbers 12-14 have two kinds of white Carrara marble in their facade coping. Further on, at number 18, the plinth of the window front is copestone of a particularly expensive sort, a blue granite, from Brazil. The window framing at number 22 is fashioned out of a grey gneiss ('stengelgneiss') probably from the Swiss Alps. The small socles at the base of the brick pillars for the arches of the colonnade are made of Triassic shell limestone ('Muschelkalk') showing an abundance of bivalves in a clayey, partially oxidised, brown-coloured matrix, from the Würzburg area in Germany.

13

On the Amorplein there is a statue of St Amor from Aquitane, who lived in the eighth century. The statue, unveiled on 0ctober 8, 1951, was designed by the Maastricht artist Charles Vos. The limestone statue is on a column of micaceous sandstone, probably from Luxemburg, which heavily flakes off and has therefore been restored with mortar in some places (Fig. 15). At the base of the pedestal is a red sandstone (Bunter sandstone) from the Moselle valley in Germany. An elegant bench made out of Carboniferous crinoid limestone was placed around the statue. 


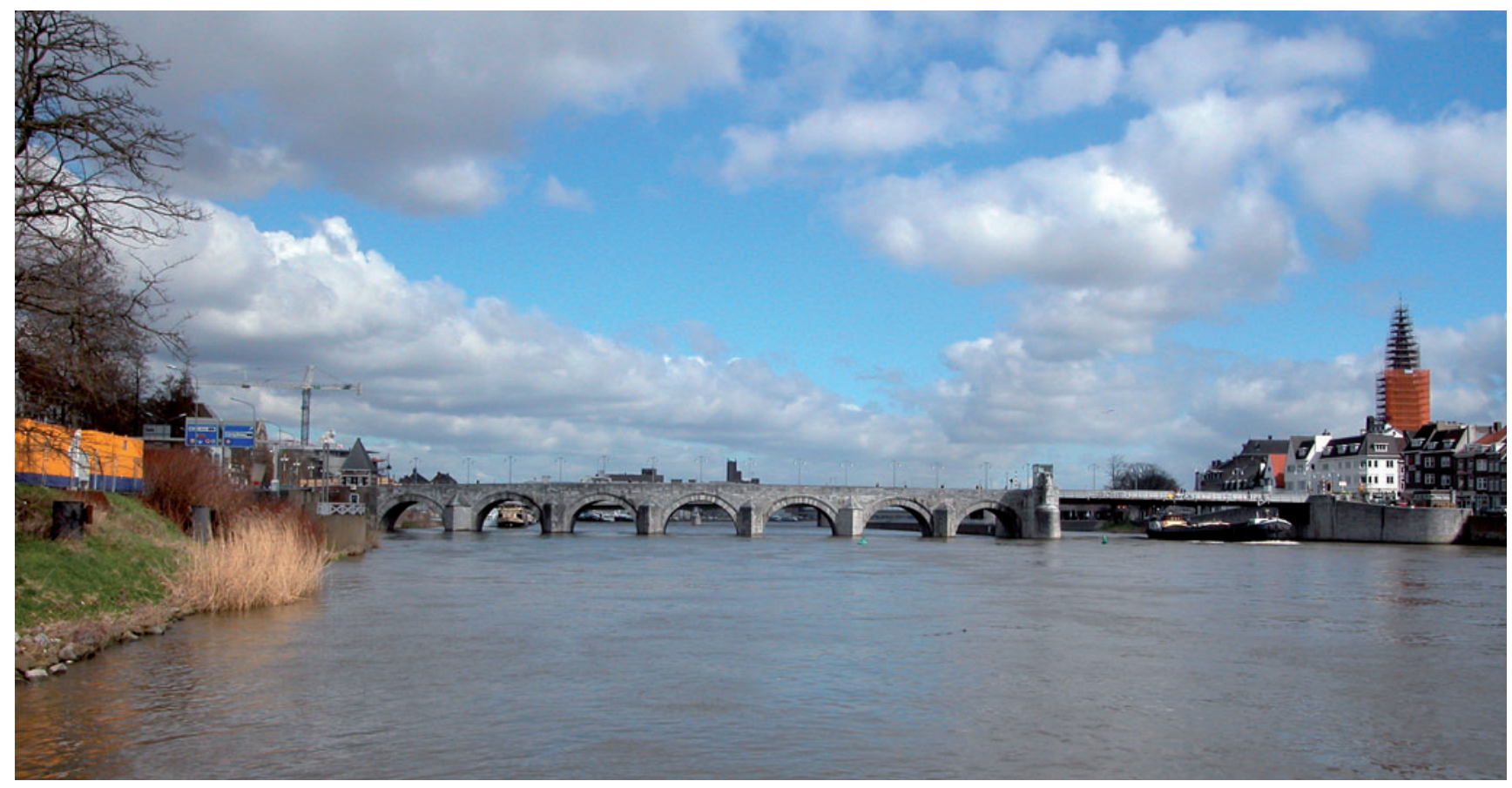

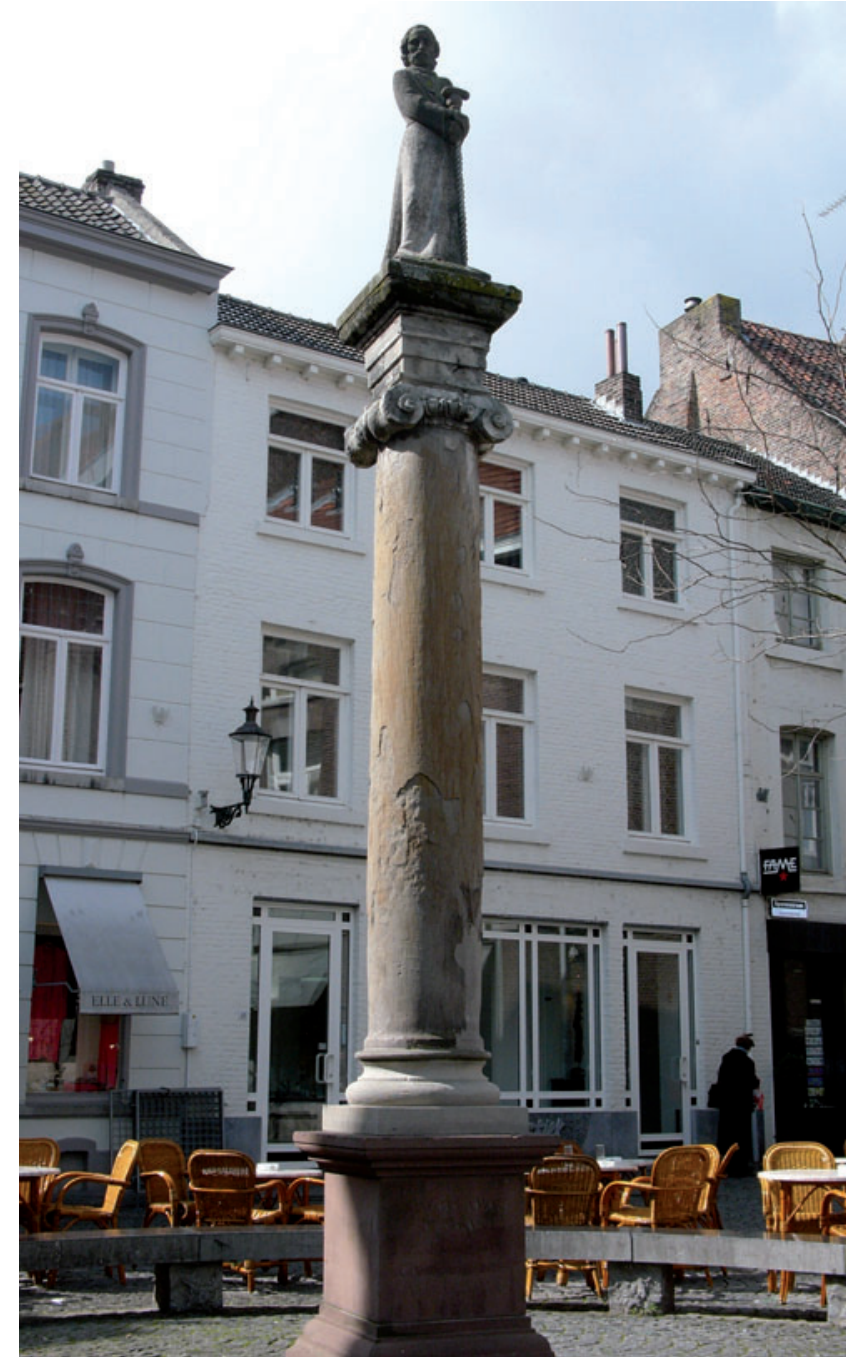

Fig. 15 St Amor statue; column of micaceous sandstone on a pedestal of Red Bunter sandstone.
Fig. 14. St Servaas bridge, restored pillars are made of Bathonian limestone from France.

\section{4}

Continuing along the Platielstraat, we arrive at Vrijthof 28, the main square of Maastricht. The St. Servaaskerk was here constructed on top of the saint's grave, from the ninth century. At the end of the twelfth century, the church was expanded to the east and the westerly portion was reinforced with two buttresses. The mediaeval building stones used were Carboniferous sandstone, Namur stone and Maastricht limestone, but because of the many additions and restorations throughout the centuries, the building is now a variegated palette of stone types (Fig. 16). There were several kinds of sandstone used, including the yellowish green, micaceous and slightly calcareous Triassic Udelfangen sandstone, that was used in the restoration phase near the end of the nineteenth century, and the red Bunter sandstone, both from Germany (Dubelaar, 2004; Dubelaar et al., 2006a). The latter was applied in the restoration performed in the 1980s. The pinnacles are built of dark grey basalt (Volvic) from the Central Plateau in France.

\section{5}

The Stadswacht (Civic Guard) building, from 1738, is covered in Namur limestone showing gastropods, colonial corals (e.g., Siphonodendron; see Fig. 17), bryozoans and crinoids. The stones also show stylolites, dissolution zones characterised by their serrated surface horizons, supposed to be formed diagenetically in consolidated rock by pressure solution. 0ther interesting details, albeit of a different nature, in this building are the grooves carved out of the freestone blocks in front of the windows, which are holders Stadwacht's weapons. 


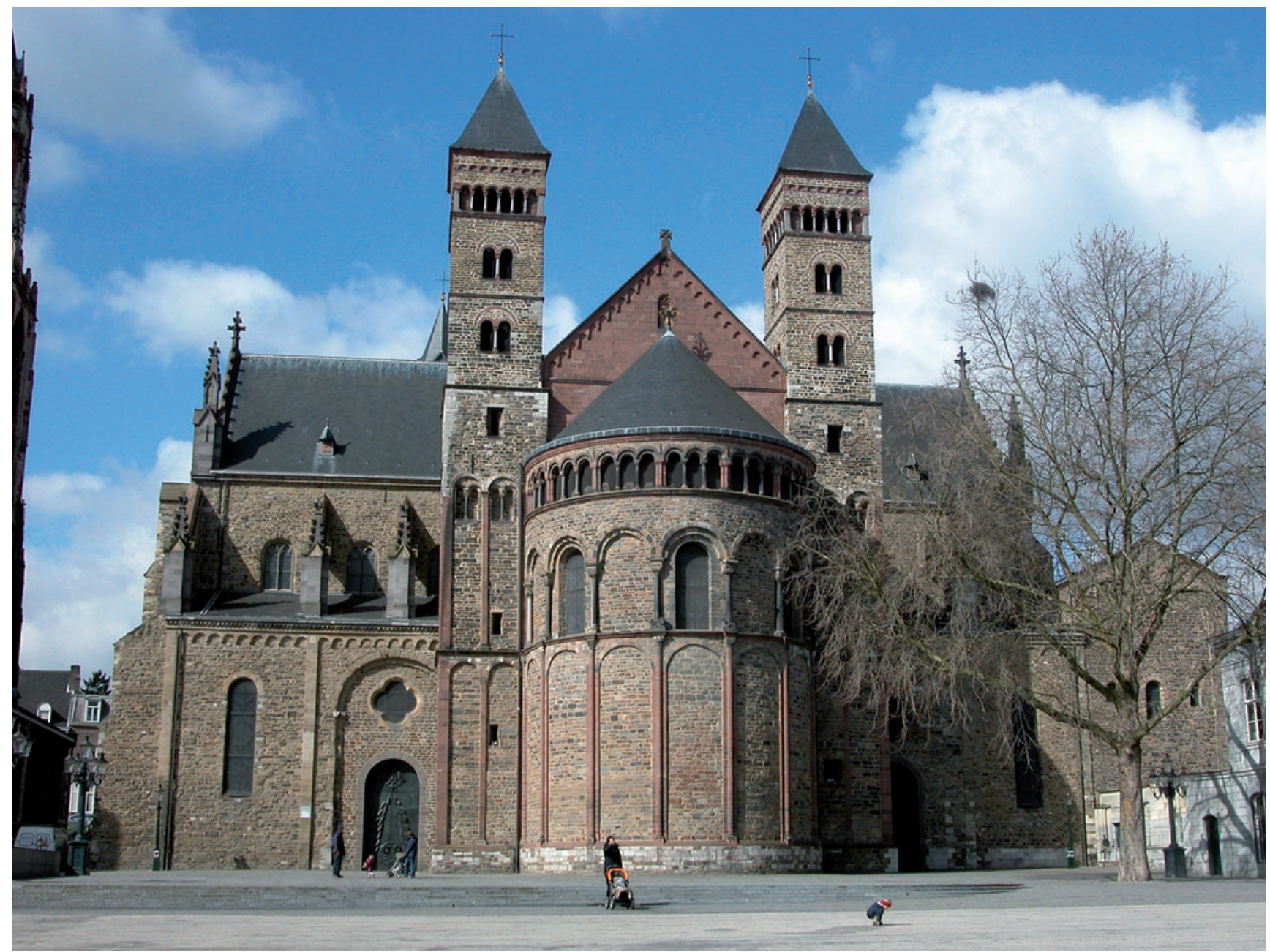

Fig. 16. St Servaas Church showing a palette of limestone and sandstone.

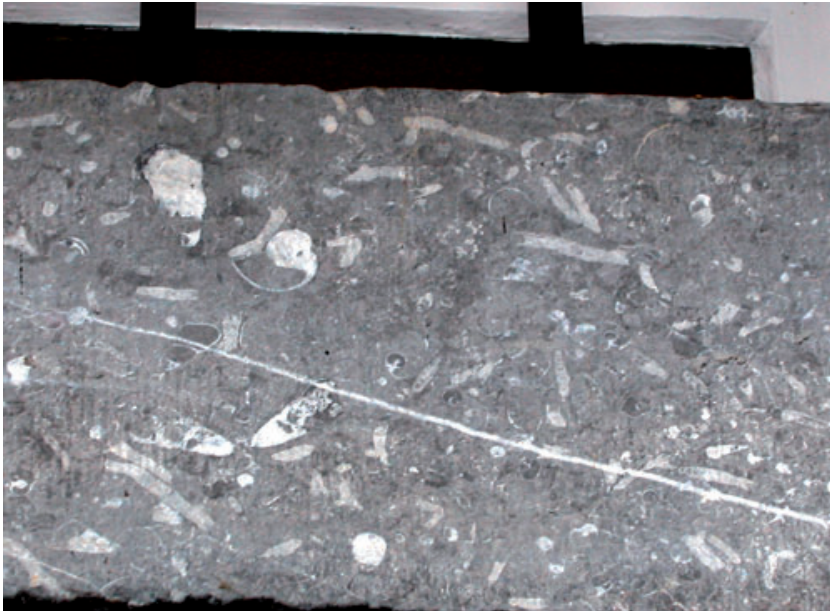

Fig. 17. Namur (Visean) limestone showing gastropods and remains of Siphonodendron thickets. Civic Guard, Vrijthof.

16

Some of the Maastricht limestone blocks, such as those in the building at St. Servaasklooster number 7, have very elegant cross-sections of echinoids (Fig. 18). These blocks are on the facade, at a height of about 2.5 metres, close to the large sandstone gate. Irregular echinoids in the Upper Cretaceous of southern Limburg varied in size from a couple of millimetres to more than 10 centimetres in length. The carbonate shell is well preserved, because many types were (semi-)infaunal burrowers. The best-known is, without doubt, Hemipneustes striatoradiatus. Umbgrove (1956, p. 130) remarked that the streets of Maastricht might well have been cobbled with them, assuming that they reproduced at an above-average rate!

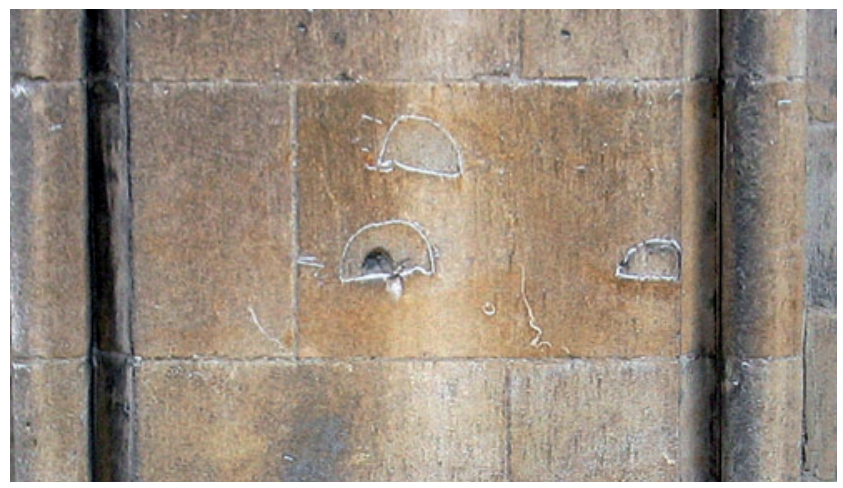

Fig. 18. Cross-sectioned tests of Hemipneustes striatoradiatus, in Upper Cretaceous Maastricht limestone blocks at the St Servaas cloister. 
17

In 1936 a women's boarding school, the Elisabeth Gruytershuis (Elisabeth Gruyters House) was designed by architect Alphons Boosten and constructed for the 'Sisters of Charity of St Charles Borromeo' at St. Servaasklooster 8-10. The door frame contains white Italian Pleistocene travertine (freshwater limestone) and the lower portion of the facade shows basalt from Niedermendig (Eifel, Germany). The superstructure has Ettringen tuff from the Eifel worked into it. The building next door has a facade of red Bunter sandstone from Germany.

\section{8}

At a height of 70 metres, the red-painted church tower of the St. Janskerk (St John's Church) on the Vrijthof dwarfs the surrounding buildings and, to a great extent, represents the silhouette of old Maastricht (Fig. 19). The church dates back to late mediaeval times; it was constructed in Gothic style in a basilica shape. The substructure is of Namur limestone, with a clear horizontal stratification caused by generations of calcareous algae. Maastricht limestone predominates above the plinth; here and there, new blocks have been set over the course of many restorations and these stand out noticeably against the older stone, which has acquired a dark yellow to dark brown, iron-enriched crust over time.

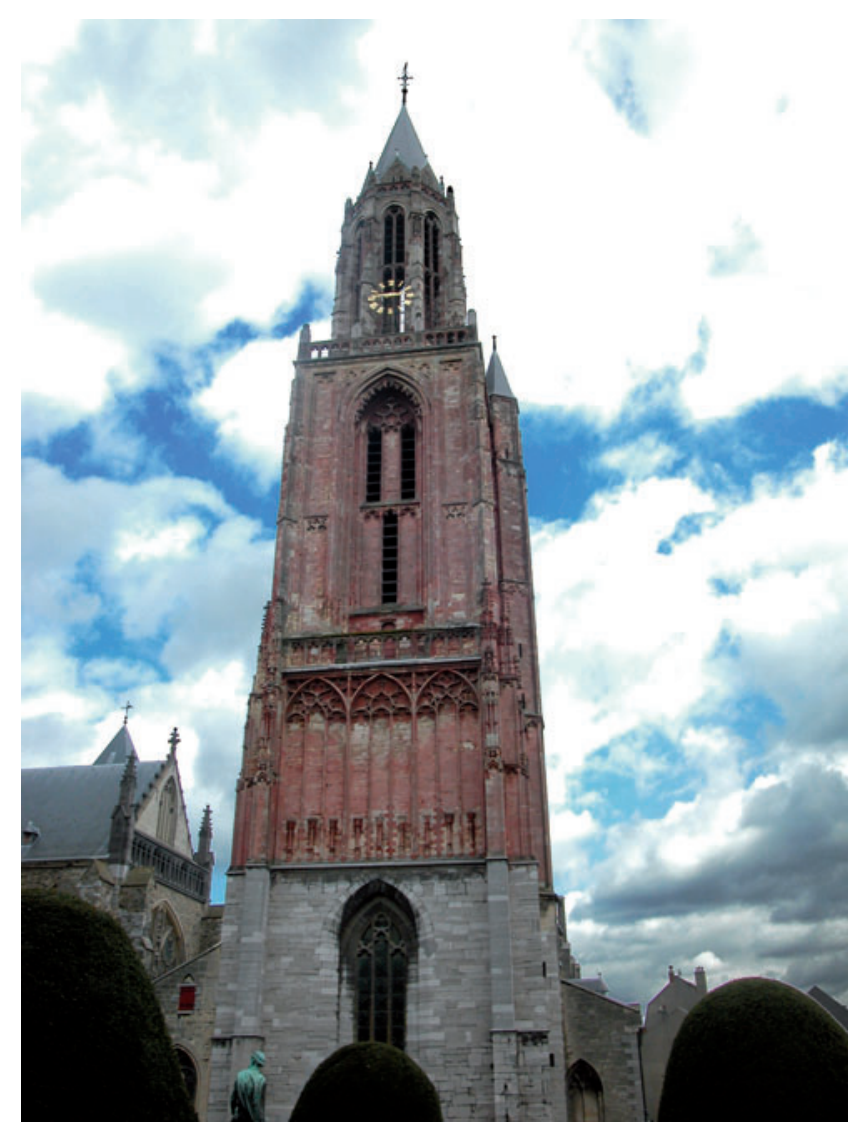

Fig. 19. Red-painted Maastricht limestone above grey Namur limestone in the tower of St John's Church.

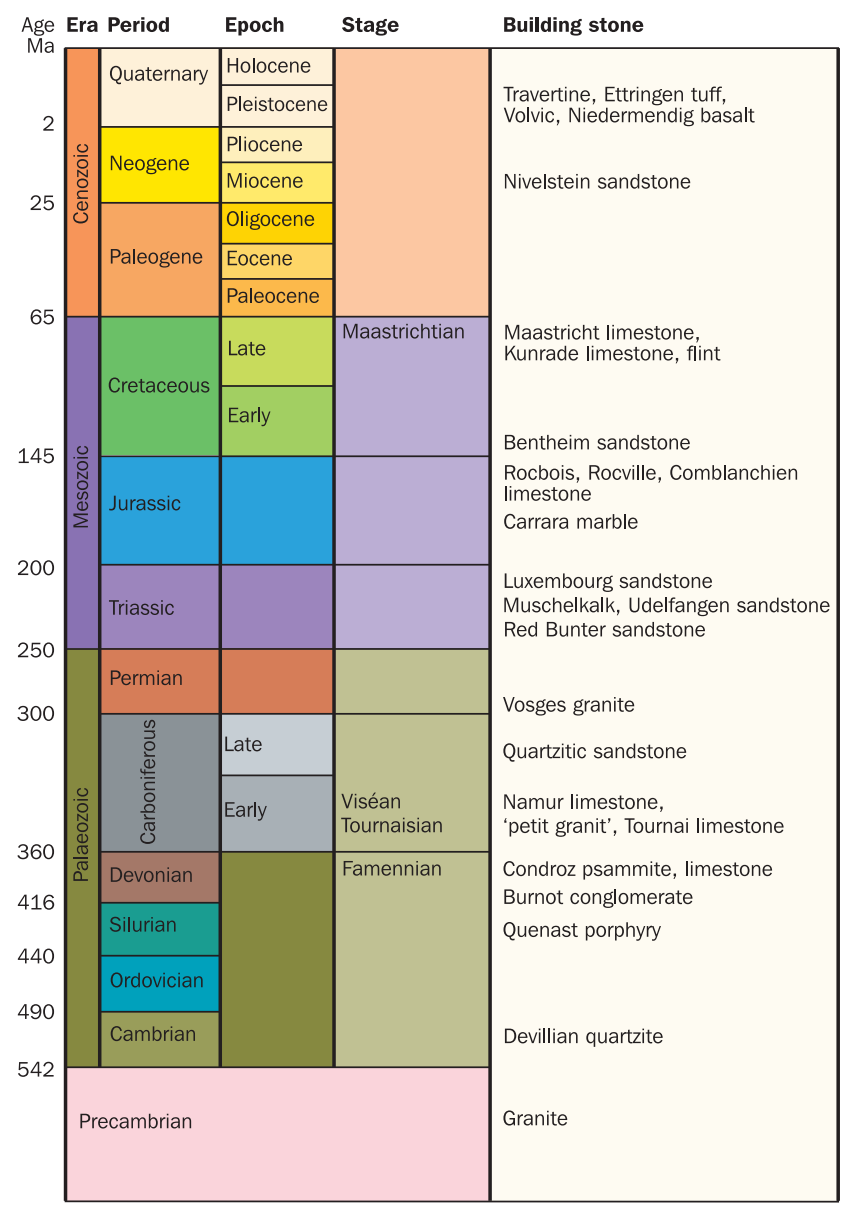

Fig. 20. Simplified geological time table with indications of age of the building stones featured in the city walk.

\section{Acknowledgements}

We thank Hans Hooghart (TNO - Geological Survey of the Netherlands, Utrecht) for permission to use his photographs (Figs 7-9, 11, 12, 13 and 15) and to Han Bruinenberg (TNO Geological Survey of the Netherlands, Utrecht) for drafting Figs 4 and 20. Editorial comments by John W.M. Jagt are also gratefully acknowledged.

\section{References}

Bosch, P.W., 1979. A Neolithic flint mine. Scientific American 240: 126-132.

Bosch, P.W., 1989. Voorkomen en gebruik van natuurlijke bouwsteen in Limburg. Grondboor en Hamer 43: 215-222.

Corteel, C. \& Van den haute, $P$., 2002. The origin of tourmalines and tourmalinites in the conglomerates of the Burnot Formation (Belgium). New petrographic and geochemical evidence. In: Degryse, P. \& Sintubin, M. (eds): Contributions to the geology of Belgium and northwest Europe. Aardkundige Mededelingen 12: $99-102$.

Dreesen, $R$. \& Dusar, M., 2004. Historical building stones in the province of Limburg (NE Belgium): role of petrography in provenance and durability assessment. Materials Characterization 53: 273-287. 


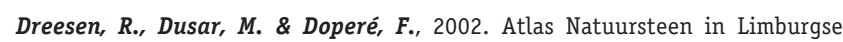
Monumenten. Geologie, beschrijving, herkomst en gebruik. Provinciaal Natuurcentrum LIKONA (Genk): 1-295.

Dubelaar, C.W., 1984. Steenrijk Amsterdam. Een geologische stadswandeling. Mededelingen van de Koninklijke Nederlandse Natuurhistorische Vereniging 35: 1-93.

Dubelaar, C.W., 2004. Mineralogy, petrophysical properties and durability of the Udelfangen sandstone (Muschelsandstein), Lower Muschelkalk, Germany. In: Prikryyl, R. (ed.): Dimension Stone 2004. New perspectives for a traditional building material. Proceedings of the International Conference on Dimension Stone, 14-17 June 2004, Prague, Czech Republic: 23-28.

Dubelaar, W., Kisters, P. \& Jagt, J.W.M., 2006a. Maastrichter steen. Een wandeling langs natuursteen in de binnenstad van Maastricht. TN0 / Natuurhistorisch Museum Maastricht (Utrecht/Maastricht): 1-16.

Dubelaar, C.W., Dusar, M., Dreesen, R., Felder, W.M. \& Nijland, T.G., $2006 \mathrm{~b}$. Maastricht limestone, a regionally significant building stone in Belgium and the Netherlands. Extremely weak, yet time-resistant. In: Fort, R., Alvarez de Buergo, M., Gomez-Heras, M. \& Vazquez-Calvo, C. (eds): Proceedings of the International Conference on Heritage, Weathering and Conservation, HWC2006, 21-24 June 2006, Madrid, Spain: 9-14.

Dusar, M., Dreesen, R. \& De Naeyer, A., 2009. Renovatie \& restauratie. Natuursteen in Vlaanderen, versteend verleden. Kluwer (Mechelen): 1-562.

Engelen, F.H.G., 1989. Vuursteenwinning en toepassing. Grondboor en Hamer 43: 207-210.

Felder, P.J., 1977. Natuursteen in Maastricht. Natuurhistorisch Maandblad 66 (Museum-nummer): 117-124.

Felder, W.M. \& Bosch, P.W., 2000. Geologie van Nederland, deel 5. Krijt van ZuidLimburg. Nederlands Instituut voor Toegepaste Geowetenschappen TN0 (Utrecht/Delft): 1-192.

Grimm, W.-D., 1990. Bildatlas wichtiger Denkmalgesteine der Bundesrepublik Deutschland. Bayerisches Landesamt für Denkmalpflege (München), Arbeitsheft 50: 1-255.

Groessens, E., 1993. L'origine et l'évolution de l'expression 'petit granit'. Bulletin de la Société belge de Géologie 102: 271-276.

Janse, H. \& De Vries, D.J., 1991. Werk en merk van de steenhouwer. Het steenhouwersambacht in de Nederlanden voor 1800. Waanders (Zwolle): 1-176.

Jongmans, W.J., 1943. Natuurlijke bouwsteensoorten van Zuid-Limburg. Mededelingen Jaarverslag Geologisch Bureau 2 (1942): 1-16.

Lijdsman, P.M.E., 1944. Bouwmaterialen natuursteen. H. Stam (Amsterdam): 1-243.

Nijland, T.G., Dubelaar, C.W., Tolboom, H.J. \& Van Hees, R.P.J., 2006. Building stones from a muddy delta: Native natural stone from the Netherlands. In: Fort, R., Alvarez de Buergo, M., Gomez-Heras, M. \& Vazquez-Calvo, C. (eds): Proceedings of the International Conference on Heritage, Weathering and Conservation, HWC- 2006, 21-24 June 2006, Madrid, Spain: 15-22.

Nijland, T.G., Dubelaar, W. \& Tolboom, H.J., 2007. De historische bouwstenen van Utrecht. In: Dubelaar, W., Nijland, T.G. \& Tolboom, H.J. (eds): Utrecht in steen. Historische bouwstenen in de binnenstad. Matrijs (Utrecht): 31-109.

Pomerol, C., 1992. Terroirs et monuments de France. Éditions BRGM (Orléans): 1-368.

Slinger, A., Janse, H. \& Berends, G., 1980. Natuursteen in Monumenten. Rijksdienst voor de Monumentenzorg (Zeist): 1-120.

Umbgrove, J.H.F., 1956. Ons land zeventig millioen jaar geleden. Levensschetsen uit de Krijtperiode. Martinus Nijhoff ('s-Gravenhage): xvi + 1-150.
Van Tussenbroek, G., 2006. The architectural network of the Van Neurenberg family in the Low Countries (1480-1640). Architectura Moderna 4: 1-250.

Van Westreenen, F.S., 1988. De geschiedenis van de onderaardse kalksteengroeven; een historisch overzicht tot 1500. S0K Mededelingen 12: 4-32. 